\title{
A.JO'ГE
}

African Journal of Teacher Education

ISSN 1916-7822. A Journal of Spread Corporation

Vol.7 No. $3 \quad 2018 \quad$ Pages 37 - 49

\section{Teaching Styles and Educational Philosophies of Secondary School Teachers in Kano Metropolis, Nigeria.}

\section{Saheed Olanrewaju Jabaar}

Faculty of Education

Yusuf Maitama Sule University, Kano Nigeria.

\begin{abstract}
The objective of the study was to examine the prevailing teaching style and educational philosophies of teachers in Kano metropolis, Nigeria, and to determine whether there was a relationship between the two variables. Descriptive survey research design was used in the conduct of the study. The population of the study consisted of a sample of 124 secondary school teachers in Kano metropolis. Robert Leahy Philosophic Inventory (1995) was adapted as data collection instrument. The data obtained were analyzed using percentage, mean, t-test and ANOVA. Findings of the study reveal that lecture method was the most frequently used teaching method by teachers while essentialism was the predominating educational philosophy of teachers. A moderate positive relationship exists between teachers' preferred teaching style and their educational philosophies but no statistically significant difference was found in the teaching styles of the male and female teachers in Kano Metropolis. Similarly, there was no significant difference in teachers' teaching styles with respect to their qualifications. Among other things, the study recommends continuous professional development of teachers through regular in-service training in order to equip them with modern and contemporary educational philosophies and teaching styles.
\end{abstract}

Keywords: Teaching styles, educational philosophy, teachers, Kano Nigeria

\section{Introduction}

It is imperative for teachers to critically recognize and utilize best teaching practices. Teaching requires knowledge of the subject matter and the skills to effectively engage learners. The best teachers conceptualize teaching as anything that might promote student learning. Many educators believe that learning is the purpose of all education. However, educators differ substantially in how 
they engineer the learning environment through their classroom teaching styles and educational philosophies.

Some educators consider the role of the teacher to be transmission of knowledge through a teacher-centered approach, while others consider the role of the teacher to be leading the student to construct knowledge through a learner-centered approach (McCarthy \& Anderson, 2000). The teacher's role in the learning process is often defined by educational philosophy. As such, the manner in which teachers view their role in the classroom, how they view the student-teacher relationship and the method of instruction, all reflect their philosophy and beliefs about education (Petress, 2003).

At the most basic level, philosophy is a love, quest or desire for wisdom, knowledge and understanding. It raises basic and fundamental questions about what we do and why we do it. A philosophy of education is a set of ideas and beliefs that guide teacher's actions and provides a framework educational practices. A clear understanding of philosophy provides a solid foundation for effective analysis of educational practices and professional growth (Conti, 2004).

Methods of teaching according to Dada (1999) relates to what a teacher does in order to provide suitable learning experiences that help the learner to interact appropriately with the subject matter in order to bring about desired, effective learning. Conti (2004) describes teaching style as the qualities and behaviors displayed by a teacher which are consistent from situation to situation regardless of curriculum content. In order words, teaching styles refer to various approaches teachers adopt in the course of teaching a particular subject and what a teacher believes is best practices to enhance learners' learning. Teaching methods and styles emanate from specific philosophy of education whether the teacher is aware of it or not.

The five traditional western philosophies which form the foundation of most educational practices are idealism, realism, pragmatism, existentialism, and reconstructionism. These western philosophies serve as a foundation and perspective for analysis of educational practices (Ozmon, 2004). The five educational philosophies have each been categorized as influencing either teachercentered or learner-centered teaching styles (Conti, 2004). Teacher-centered teaching styles are consistent with traditional philosophies of idealism and realism, and the educational philosophies of liberalism and behavioralism. Learner-centered styles on the other hand, are consistent with philosophies of pragmatism, existentialism and reconstructionism, progressivism, humanism and realism (Conti, 2004; Zinn, 2004). 
Teacher-centered style is defined as a formal, controlled, and autocratic instructional style which assumes that learners are passive. Learner-centered style on the other hand, is defined as a pattern of instruction that is responsive, problem-centered, democratic and employs a collaborative learning environment which enables critical thinking rather than mere collection of facts. (Weimer, 2002)

A number of studies have been conducted on teachers' teaching styles and their educational philosophies. Uyangor et' al (2016) conducted a study on student teachers at Necatibey University Faculty of Education and teachers working in Karesi and Altieylal provinces of Balikesir in Turkey during the 2014 - 2015 academic year to determine their preferred teaching philosophies. It was reported that progressivism and re-constructionism, which are based on contemporary approach to education, are preferred to essentialism and perennialism philosophies, which advocate more traditional approaches. Ghazieni (2014) investigated the educational philosophy and philosophical mindedness of Iranian physical education and sport science teachers. It was reported that experimentalism and realism were the first and second educational philosophy of Iranian physical education lecturers. It was also reported that comprehensiveness, penetration and flexibility are their first, second and third philosophical mindedness preference respectively. Bicer (2013) conducted a study to determine teachers' educational philosophies about teaching and learning activities in a Turkish state university education department's pedagogical training program. According to the study, philosophy group teacher candidate adopted the existentialist philosophy the most while they adopted the essentialist philosophy the least. It also reported that there were no differences among teacher candidate in their educational philosophies on the basis of gender and educational status variables, except that more female teacher candidates adopted essentialism.

Considering the importance of education, there is the need to make sure that students are properly taught. The poor achievement of students in public secondary schools has been associated with the use of poor teaching styles and lack of retention by the students. In view of these, education researchers have always been searching for better teaching styles and fitting education philosophy of teachers to enhance students' achievement. The purpose of this study, therefore, is to describe and examine the teaching styles and the educational philosophies of teachers in public secondary schools in Kano metropolis, so also to determine the extent to teachers are adopting contemporary teaching styles that can promote learning and students' retention of the subject matter. 
The scope of the study will be limited to Public secondary schools within Kano Metropolis. The study will be specifically carried out in six randomly selected public secondary schools, one from each local government of the metropolis. The study seeks to answer the following research questions:

1. What are the prevailing teaching styles of the teachers in the public secondary schools in Kano metropolis?

2. What are the prevailing educational philosophy of teachers in public secondary schools in Kano metropolis?

3. Is there a relationship between teachers preferred teaching styles and their educational philosophies?

The study seeks to address the null hypothesis which states: is there a difference in teacher's teaching style in the basis of gender, qualification sex?

\section{METHODOLOGY}

\section{Research Design}

This study adopted the use of descriptive survey research design. The design was considered suitable for the study since data will be collected from the respondents through the use of questionnaire. Descriptive research gives a picture of a situation or a population. The population of the study consists of all the secondary school teachers in Kano metropolis. There are nine local governments within Kano metropolis. Six out of the nine local government were randomly selected. Thus, for this study, secondary school teachers within Kano metropolis constitutes the population of the study.

The sampling technique adopted in this study is the simple random sampling. Simple random sampling technique as a form of probability sampling which gives each member of the population equal and independent chance of being selected and the selection of an individual does not in any way affect the selection of the other. The sample size of this study was 124 randomly selected teachers across the six schools under study. The sample size was drawn using table for the determination of sample size developed by researchers' advisors (2006). Thus, the figure (124) serves as representative of the larger population. Table 3.1 provides a breakdown of the study population. 
Table 3.1 Sample of the study

\begin{tabular}{lc}
\hline Schools & Number of Teachers \\
\hline Governors' College & 36 \\
Army Day Secondary School Bukabu & 36 \\
Government Girl Secondary School Magwan & 34 \\
Government Girl Secondary School Kofar Mazugal & 37 \\
Government Secondary School Kofar Na'isa & 37 \\
Government Girl Secondary School Hausawa & 34 \\
Total & 214
\end{tabular}

The researcher used structured questionnaire to collect data for the study. The researcher adapted Robert Leahy Philosophic Inventory (1995) as data collection instrument for determining educational philosophies of teachers while the aspect of teachers' teaching styles were developed by the researcher. The questionnaire consisted of three sections, A, the bio-data of respondents, B, teaching philosophy and $\mathrm{C}$, teaching style. The questionnaire was developed on four points Likert scale ranging from 4 strongly agree to 1 strongly disagree. Items in the questionnaire were generated in line with the objective of the study. The instrument was validated by two experts in the philosophy of education and two experts in instructional technology in order to check the suitability of the language and appropriateness of the questions. Reliability of the instrument was determined using Cronbach's alpha to determine the internal consistency of the instrument. This was done after the instrument was administered on a few respondents who were not part of the target population. The internal consistency reliability coefficient obtained for the instrument was .825 and .849 for sections B and C respectively. These indicated that the instrument was reliable enough. The data was analyzed using excel and statistical package of social sciences (SPSS). Frequency count, percentages, mean, independent sample t-test and analysis of variance (ANOVA) were used in analyzing the data and determining the differences between the study variables.

\section{DATA PRESENTATION AND ANALYSIS}

The participants in this research are the teachers of senior secondary school students in Kano metropolis. The demographic information of the respondents is presented on table 4.2.1 below:

Table 4.2.1: Demographic Characteristics of the Respondents (124) 


\begin{tabular}{llcc}
\hline Variable & \multicolumn{1}{c}{ Level } & Frequencies & $\%$ \\
\hline Gender & Male & 62 & $50 \%$ \\
& Female & 62 & $50 \%$ \\
\hline Qualification & NCE & 71 & $57.3 \%$ \\
& B.A/Sc/B.Ed & 35 & $28.2 \%$ \\
& M.Sc. & 18 & $14.5 \%$ \\
\hline Experience & Less than 1year & 21 & $16.9 \%$ \\
& 1-3 Years & 28 & $22.6 \%$ \\
& 4-5 years & 27 & $21.8 \%$ \\
& 5- Above & 48 & $38.7 \%$ \\
\hline
\end{tabular}

Source: Field study (2017)

Table 4.2.1 above presents the distribution of the respondents based on gender qualification and experience. The distribution based on gender shows that $62(50 \%)$ of the respondents were male while $62(50 \%)$ of the respondents were female. distribution based on qualification shows that 71 (57.3\%) of the respondents were NCE holders, 35 (28.8\%) of them were graduate teachers while only $18(14.5 \%)$ were Masters degree holders. Similarly, distribution based on experience shows that majority of the respondents 48 (38.7\%) have a teaching experience of 5 years and above. Those with less than 1 year teaching experience are the least 21 (19.9) while those with 1-3 years and 4-5 years teaching experience were $28(22.6 \%)$ and 27 (21.8\%) respectively.

The results are presented under each research question/hypothesis and interpreted in relation to previous studies.

Research Question One (1): What are the prevailing teaching styles of the teachers in the public secondary schools in Kano metropolis?

To answer the above question, the teachers' teaching styles were measured in this study through the administration of designed and validate questionnaire. The results of teachers' teaching styles are presented on table 4.3 .1 below: 
Table 4.3.1: Teaching Styles in Public Schools

\begin{tabular}{llcccc}
\hline S/N & Teaching style & Scores & F & \% & Mean (SD) \\
\hline 1 & Lecture Method & 8 & 49 & $39.5 \%$ & $3.3(0.74)$ \\
2 & Demonstration Method & 8 & 20 & $16.1 \%$ & $2.9(0.82)$ \\
3 & Activity Method & 8 & 20 & $16.1 \%$ & $3.0(0.80)$ \\
4 & Questioning Method & 8 & 18 & $14.5 \%$ & $2.9(0.79)$ \\
5 & Discovery Method & 8 & 17 & $13.7 \%$ & $3.1(0.77)$ \\
& & & & &
\end{tabular}

Source: Field study (2017)

Table 4.3.1 describes the teaching styles of teachers in public schools. The table indicates that lecture method is the most frequent style of teaching used in public schools with the highest frequency of 49 $(39.5 \%)$. The table also reveals that discovery style of teaching is the least used method of teaching in public school with frequency of only 17 (13.7\%). Demonstration and activity methods of teaching styles are the second most used style of teaching in public schools with frequency of 20 (16.6\%).

This finding is consistent with the submission of Abimbola (2008) who opined that lecture method is still the most widely used form of teaching in Nigerian schools. He submitted that lecture method is still the best method for teaching students new concepts and principles. In the view of Siagh and Rana (2004), the lecture method has received more criticisms than any teaching strategy yet it continues to be used extensively. This indicates that the majority of teachers in Nigerian schools still consider lecture method as one or the most efficient ways of teaching. This is not unconnected with the fact teachers are likely to teach the way they have been taught.

Research Question Two (2): What are the prevailing educational philosophies of teachers in public secondary schools in Kano metropolis?

To answer the above question, the teachers' educational philosophies were measured in this study through administration of designed and validate questionnaire. The results of teachers' educational philosophies are presented on table 4.3.2 below: 
Table 4.3.2: Teachers Educational Philosophy in Public Schools

\begin{tabular}{llcccc}
\hline S/N & Educational Philosophy & Scores & F & \% & Mean (SD) \\
\hline 1 & Essentialism & $18-20$ & 48 & $38.7 \%$ & 16.33 \\
& & & & & $(3.07)$ \\
2 & Progressivism & $18-20$ & 24 & $19.4 \%$ & 15.69 \\
& & & & & $(3.14)$ \\
3 & Existentialism & $18-20$ & 23 & $18.5 \%$ & 18.15 \\
& & & & & $(3.47)$ \\
4 & Reconstructionism & $18-20$ & 29 & $23.4 \%$ & 14.79 \\
& & & & & $(3.11)$ \\
\hline & & & $\mathbf{1 2 4}$ & $\mathbf{1 0 0 \%}$ & $\mathbf{1 6 . 2 4}(\mathbf{2 . 2 8})$
\end{tabular}

Source: Field study (2017)

Table 4.3.2 ranked essentialism as the most prevailing educational philosophy of teachers in public secondary schools in Kano metropolis with frequency value of 48 (38.7\%). The table also reveals that progressivism is the second most prevailing philosophy while existentialism is the least with. $18.5 \%$.

This finding is not consistent with Uyangor (2016) who reported that progressivism and reconstructionism philosophies which are based on contemporary approach to education, are preferred essentialism which advocate traditional approaches. The finding of this study is not consistent with the findings of Ghazieni (2014) which shows that experimentalism and realism were the first and second educational philosophy of Iranian physical education lecturers. In the same vein, Bicer (2013) investigated teacher candidates' educational philosophies about teaching and learning in Turkey and reported that a majority of the teachers adopted the existentialist philosophy while a minority adopted essentialist philosophy. This is also inconsistent with the findings of this study. This may be attributed to the fact that most of the studies were conducted in Asia and the Global North where contemporary philosophies of progressivism and existentialism are gaining popularity and teachers have access to modern and contemporary information about teaching and learning. Most 
teachers in Kano metropolis still hold on to the traditional philosophy and method of teaching probably as a result of lack of information about current developments in education or as a result of their training while they were students.

Research Question Three (3): Is there a relationship between teachers preferred teaching styles and their educational philosophies?

Table 4.3.3: Correlation between Teaching Styles and Educational Philosophies

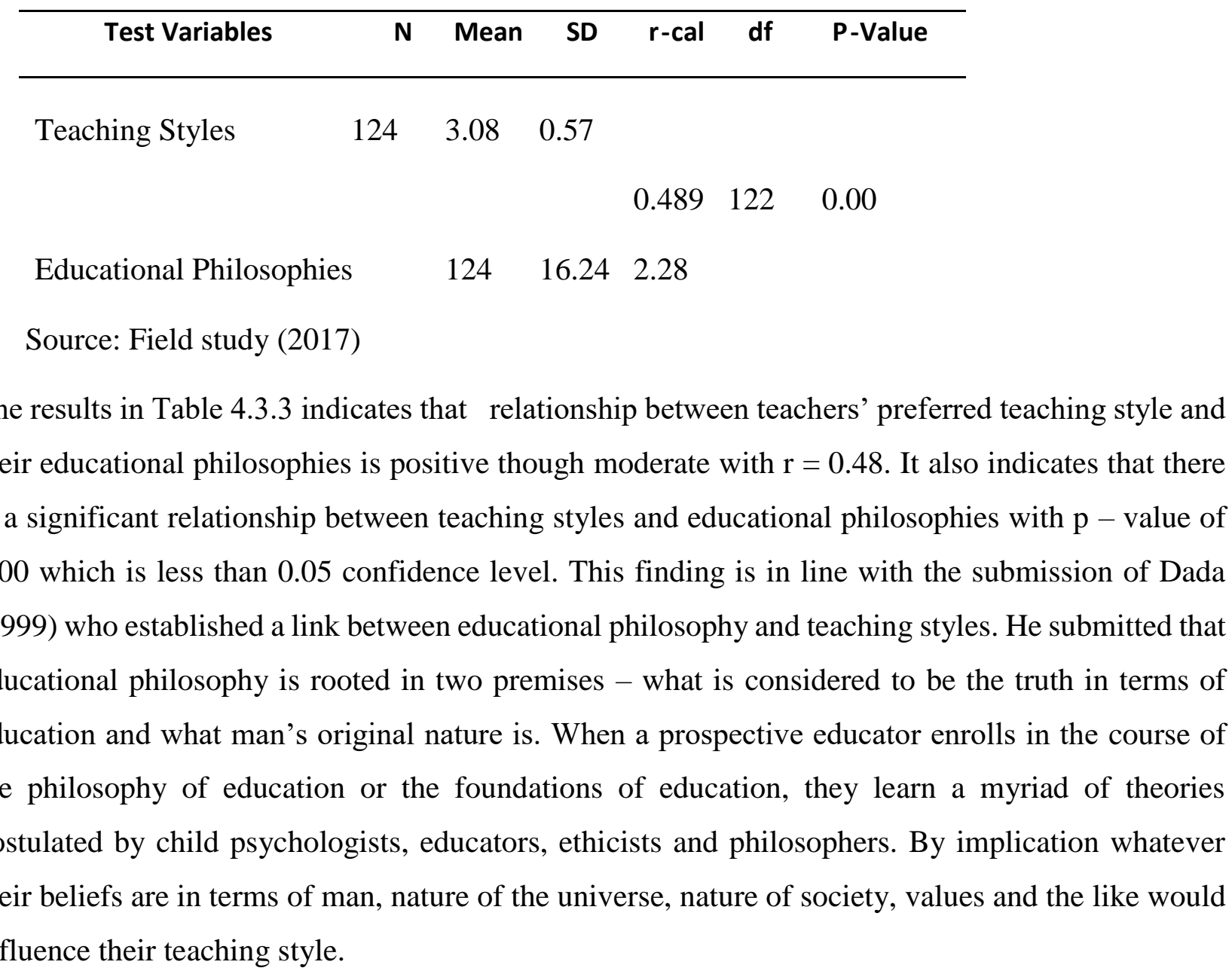

Hypothesis One (Ho1): There is no significant difference in teacher's teaching style on the basis of gender and qualification.

To test the above hypothesis, the teaching style scores of female and male teachers as well as their scores on the basis of their qualification were used to conduct an independent sample $\mathrm{t}$ - test for gender and ANOVA for qualification, the results of the analysis are presented on table 4.3.2 below; 
Table 4.3.4: Teaching style in Public School (Gender)

\begin{tabular}{|c|c|c|c|c|c|c|c|c|}
\hline & Gender & $\mathbf{N}$ & Mean & S.D. & t-cal & Df & P-value & $\mathrm{HO}_{2}$ \\
\hline \multirow[t]{3}{*}{ Teaching Style } & Male 62 & & 3.11 & 0.53 & & & & \\
\hline & & & & & 0.683 & 122 & $0.496 A$ & Accept \\
\hline & Female 62 & & 3.04 & 0.62 & & & & \\
\hline
\end{tabular}

Field study (2017)

The results presented in Table 4.3.4 indicate that there is no statistically significant difference in the teaching styles of male and female teachers in Kano Metropolis. The mean score for male teachers is 3.11 while the mean scores of female teachers is 15.11 . The difference is not significant because the Sig ( 2 tailed) which is 0.496 is greater than 0.05 . This finding is consistent with the findings of Bicer (2013) that there were no differences among the teachers surveyed in their educational philosophies on the basis of their gender.

Table 4.3.5: Teachers' Teaching Style (Qualifications)

\begin{tabular}{|c|c|c|c|c|c|c|c|}
\hline \multicolumn{2}{|l|}{ Test Variables } & $\begin{array}{l}\text { Sum of } \\
\text { Squares }\end{array}$ & Df & $\begin{array}{c}\text { Mean } \\
\text { Square }\end{array}$ & $\mathbf{F}$ & Sig. & Ho2 \\
\hline \multirow{3}{*}{ Teaching Style } & Between Groups & 1.865 & 2 & 0.932 & 2.882 & 0.060 & \\
\hline & Within Groups & 39.143 & 121 & 0.323 & & & Accept \\
\hline & Total & 41.007 & 123 & & & & \\
\hline
\end{tabular}

Source: Field study (2017)

The result for the test for differences using the one - way ANOVA obtained, as shown in Table 4.3.2, shows that the F statistics $(121)=2.88$, and $p$ value $=0.06, \alpha=0.05$ the result of the analysis reveals that the teaching styles of the teachers are not significantly different with respect to their qualifications because the $\mathrm{p}-$ value is greater than the alpha value of 0.05 . The null hypothesis which says that there is no significant difference in teachers' teaching styles with respect to their qualifications is accepted. This finding is consistent with Bicer's (2013) study which reported that 
there were no differences among the teachers surveyed in their educational philosophies on the basis of their educational status variable (qualification)

Based on the findings of the study, the following inferences were made:

1. Lecture method was the most frequently used teaching style among public school teachers in Kano Metropolis.

2. Essentialism was the most prevailing educational philosophy of teachers in public secondary schools in Kano metropolis.

3. A statistically significant positive relationship exists between teachers' teaching style and their educational philosophies.

4. There is no statistically significant difference in the teaching styles of teachers on the basis of gender and qualification of teachers in Kano Metropolis.

\subsection{Recommendations}

Based on the findings of this study, the following recommendations were made:

1. There should be continuous professional development of teachers through regular in-service training in order to equip them with modern and contemporary philosophies and teaching methods.

2. Secondary school teachers should be employing a teaching method that would facilitate the achievement of lessons' objective. Thus they should avoid uncritical use of a given method in all their lessons.

3. Secondary school teachers should adopt philosophical assumptions that fit in well with contemporary approaches to education. This greatly facilitate easy transfer of knowledge.

4. Workshop and seminars should be organized for secondary school teachers of all cadres and gender in order to expose them to contemporary educational philosophies and teaching styles so as enhance their competence in teaching.

\section{Reference}

Abe, T.O. (2014). The effect of teachers' qualification on students' academic performance in Mathematics. Sky Journal of Educational Research 2(1) Retrieved on the $16^{\text {th }}$ July 2015 from www.skyjournal.org/SJER 
Abimbola, O. (2004 Jan 20). Schooling Issues: ICT for Teaching and Learning. Department of Education, Employment and Workplace Relations. Retrieved from $\underline{\text { www.emeraldinsight.com/journal.htm }}$

Adhan, A. A.\& Smith, E.(2010). The social functions of education in a developing country: The case of Malaysia. Journal of Intercultural Education 12(3):325-337.

Bicer, B. (2013). Philosophy group teacher candidates' preferences with regard to educational philosophies of teaching and learning activities. Anthropologist, 16 (3), 428

Conti, G. (2004). Identifying your teaching style. In M.W.Galbraith (Ed.), Adult learning methods (3rd ed.).Malabra, FL: Kreiger Publishing.

Cook, C. (2008). Philosophical foundations of US education. Retrieved from www.myeducationlab.com on the $12^{\text {th }}$ July 2016

Dada, A. (1999). Teacher and the curriculum. Ibadan: Tajama General Enterprises.

Ghazieni, F.G. (2014). Preference of educational philosophy and philosophical mindedness of Iranian physical education and sport science lecturers. Annals of Applied Sport Science, 2(1), 81-86. Retrieved from www.aassjournal.com

Kauchak, D. and Eggen, P. (2011). Introduction to teaching: Becoming a professional (4th ed.). Boston: Pearson Education, Inc.

McCarthy, J. P, \& Anderson, L. (2000). Active learning techniques versus traditional teaching styles: Two experiments from history and political science. Innovative Higher Education, (24) 4, 279-294, (AN 14990493)

Noddings, N. (1995). Philosophy of Education. USA: Westview Incorporated.

Ozmon, H.A., and Craver, S.M. (2003) Philosophical Foundations of Education. Upper Saddle River, NJ: Pearson Education, Incorporated.

Petress, K. (2003). An educational philosophy guides the pedagogical process. College Student Journal. (37)1, 128-134

Robert, L. (1995 Feb.2015). Becoming a teacher. Retrieved from http:// www.myeducationlab.com Rocha. (2014). A primer for philosophy and education. Oregon: Cascade Books. 
Scheffler, I. (1960). Language of education. Springfield III: Charles C. Thomas.

Siagh, O. \&Rana, I. (2004). Aristotle, The Politics of Aristotle: With an Introduction, Two Prefatory Essays and Notes Critical and Explanatory, Clarendon Press, 1887.

Uyangor, N. \&Sahan, H.H. (2016). An analysis of educational philosophies and teacher competencies. International Journal of Current Research. Vol.8 issue 04. Retrieved from www.journalcra.com

Weimer, M. (2002). Learner - centered teaching: five changes to practice. San Francisco: Jossey Bass.

Zinn, L.M. (2004). Exploring your philosophical orientation. In M.W. Galbraith (Ed.), Adult learning methods (3rd ed.), 39-74. Malbar, FL:Kreiger Publishing Company http://pqdtopen.proquest.com/doc/1039150189.html?FMT=AI(Assessed 2017-04-05) 